\title{
Needs Analysis to Develop a Practice Assessment Instrument for Learning Process During Covid-19 Pandemic
}

\author{
Wulansari Prasetyaningtyas ${ }^{1,2 *}$ Sri Wening ${ }^{1,2}$ \\ ${ }^{1}$ Educational Research and Evaluation Study Program, Universitas Negeri Yogyakarta, Indonesia \\ ${ }^{2}$ Fashion Education Study Program, Universitas Negeri Semarang, Indonesia \\ ${ }^{*}$ Corresponding author. Email: wulansariprasetyaningtyas.2021@student.uny.ac.id
}

\begin{abstract}
Student achievement levels in learning can be determined through assessment. Covid-19 pandemic resulted in the changes of the learning system, including the assessment process. The study identifies the need to develop practice assessment instruments during the Covid-19 pandemic in the Fashion Design Education Program. The assessment practice was measured using an instrument development based on the ADDIE (Analyze, Design, Develop, Implement, and Evaluate) model development stage, i.e., the needs analysis stage. The data were collected using a questionnaire, with a total sampling technique of 11 lecturers who teach practical courses in the Fashion Design Education Program. The data were analyzed by descriptive percentage analysis. The research reveals that 11 lecturers teaching practical courses have used practical assessment instruments, 54.5\% of the assessment instruments used have not been equipped with rubrics. $90.9 \%$ compiled by the supporting lecturers were not tested for validity by the study group, 63.6\% practice assessment instruments did not use pre-practice, practice, and post-practice components, and $81.8 \%$ found difficulties in preparing practical assessment instruments.
\end{abstract}

Keywords: assessment instrument, covid 19 pandemic, learning process, practice assessments.

\section{INTRODUCTION}

Providing the proper assessment can improve student learning outcomes in practical courses. The proper assessment can improve learning, as assessment can document learning [1]. Assessment is an activity used to determine the achievement of learning outcomes [2]. Student learning outcomes in accordance with Bloom's taxonomies are differentiated into affective, cognitive, and psychomotor domains [3]-[5].

Pandemic covid 19 is one of the disasters that claimed the earth's population. Covid 19 began entering Indonesia in March 2020 [6]. The world of education is now starting to feel the impact of the coronavirus diseases pandemic (Covid 19). [7]. The impact resulted in teachers providing online learning or distance education from home [8]. This online learning has been carried out ranging from primary education to higher education since the pandemic outbreak of pandemic covid 19 into Indonesia. Online learning is expected to reduce the rate of spread of the Covid-19 virus in Indonesia.

The policy implemented in the world of education in Indonesia has four main points in accordance with the circular letter of the Minister of Education and Culture (Mendikbud) of the Republic of Indonesia Number 3 of 2020 on the prevention of coronavirus or COVID-19 in the Ministry of Education, and the Secretary-General's Letter as of March 12, 2020, regarding the postponement of events involving many people and based on the Decree of the Minister of Education No. 4 of 2020, which contains the implementation of education policies in the emergency phase of the coronavirus pandemic. The four main points are 1) learning is done online or remotely from their respective homes to provide a learning experience without 
burdening students to complete targets that are following the curriculum; 2) life skills education is more focused on distance learning or online learning; 3) the provision of assignments to students is tailored to interests and conditions with regard to the conditions and facilities owned by students, and 4) the provision of feedback on the manufacturing process and product results are given qualitatively without providing quantitative scores.

The online learning policy is also applied at Universitas Negeri Semarang. Online learning has been carried out from March 16, 2020, until now. This policy refers to the circular letter of the Rector of Universitas Negeri Semarang (UNNES) Number: B/ 1413 / UN37 / 2020 on Vigilance and Prevention of the Spread of Covid-19 Infection in the Academic and Public Services Sector in the Environment of Universitas Negeri Semarang and Rector Circular Letter Number: B / 1502 / UN37 / WS / 2020 on Employee Work Arrangements in the Framework of Covid 19 Prevention in the UNNES Environment, learning is carried out online from March 16, 2020, until now. Although currently there is limited face-to-face learning with a combination of hybrid learning, it is only applied to theory courses. In practical courses, online learning remains in place.

Practical learning that is carried out online many encounter obstacles, one of which lecturers cannot provide material with the right media and methods. The evaluation system cannot be done optimally because lecturers can only see the results of student work through video recordings or photos. In addition, students cannot receive materials provided by lecturers properly, and some students also do not have sewing. Related to the evaluation system that has not been able to be done optimally, it can have an impact on the learning outcomes obtained by students at the end of learning.

Assessment instruments relate directly to the quality of learning where the nature of measurement is through evaluation and assessing the quality of learning required standard criteria in assessment [9]. Assessment instruments have an important role in determining the quality of learning and student learning outcomes. Assessment of practical course learning on the UNNES Fashion Education Study program conducted during the Covid 19 pandemic does not have standards. This can be known from the many complaints from lecturers who find it difficult to conduct product assessments because they cannot observe and see directly both in the preparation, manufacturing process and in the completion of the manufacture of products/tasks given by lecturers.

This is behind the research on analyzing the needs of practice assessment instruments in the UNNES Fashion Education study program during the Covid 19 pandemic. Researchers have widely researched the development of practical instruments and the analysis of the needs of practice assessment instruments, including those conducted in [10]-[14].

On the practical learning in the UNNES Fashion Education Study Program, lecturers can only see the results of student practice through photos or video recordings with a short duration, so it cannot be maximized in providing assessments. The absence of standard instruments also exacerbates this to measure students' ability in practice courses. By problems as mentioned earlier, this study aims to analyze the needs of instrument development in practical courses in the UNNNES Fashion Education Study Program.

\section{METHOD}

This research is descriptive research used to analyze the needs of assessment instruments in practical courses in the Fashion Education Study Program of UNNES. The population in this study is all lecturers who master practice courses in the UNNES Fashion Education Study Program, which were 11 lecturers. Sampling techniques use total sampling, i.e., the entire population is sampled in this study.

The data collection technique used google formassisted questionnaires in the spread of the questionnaire. Before use to retrieve data, research instruments must be proven the validity of the instrument and be able to be used to estimate the consistency and stability of assessment results. Validity refers to the extent to which evidence and theories support the interpretation of test scores required by the proposed use of the test [15]. This study's validity is proven by the validity of the contents using Aiken's V formula. The Aiken formula is used to calculate the proof of the content validity based on the results / expert opinions of an item in an instrument in which the item must represent what is to be measured [16].V Aiken's formula can be written as.

$V=\sum s /[n(c-1)]$

Description:

$\mathrm{V}=$ validity index of Aiken

$\mathrm{S}=\mathrm{r}-\mathrm{lo}$

lo = lowest validity assessment number

$\mathrm{C}=$ highest validity assessment number

$\mathrm{n}=$ number of raters

$r=$ number given by the rater

The item analysis results can be said to be valid if it meets the $\mathrm{V}$ Aiken limit. Proof of validity in this research instrument uses five raters and five rater scales. 
Based on Table V Aiken above, the limit requirement of the rater coefficient of each item is 0.80 with a probability of 0.40 . Each statement item on the practice assessment instrument's instrument needs analysis gets an Aiken $\mathrm{V}$ score above 0.80. Therefore, all four instruments are declared valid to be suitable for use in data retrieval. The results of the content validity test using the formula V Aiken can be seen in Table 1.

Tabel 1. Result of validity calculating using V Aiken formula

\begin{tabular}{|c|c|}
\hline Items & Calculation results \\
\hline 1 & 0.82 \\
\hline 2 & 0.87 \\
\hline 3 & 0.90 \\
\hline 4 & 0.84 \\
\hline 5 & 0.81 \\
\hline 6 & 0.90 \\
\hline 7 & 0.83 \\
\hline 8 & 0.81 \\
\hline 9 & 0.88 \\
\hline 10 & 0.89 \\
\hline 11 & 0.90 \\
\hline 12 & 0.91 \\
\hline 13 & 0.86 \\
\hline 14 & 0.81 \\
\hline 15 & 0.84 \\
\hline 16 & 0.95 \\
\hline
\end{tabular}

Instrument reliability is estimated using the Interclass Correlation Coefficient (ICC) with the help of the SPSS 22 application. The results of the analysis are summarized in Table 2. Interpretation based on the analysis of instruments used to analyze the requirements of instruments in practical courses in the UNNES Fashion Education Study Program is the ICC Score showing the level of excellent estimation in the range of $0.75-1.00$ [18]. It can be concluded that the assessment device is capable and can be used to analyze the needs of assessment instruments in practical courses in the UNNES Fashion Education Study Program.

\begin{tabular}{|c|r|r|r|r|r|r|r|}
\hline & \multirow{2}{*}{$\begin{array}{c}\text { Intra- } \\
\text { class } \\
\text { Correl- } \\
\text { ation }\end{array}$} & \multicolumn{2}{|c|}{$\begin{array}{c}95 \% \\
\text { Confidence } \\
\text { Interval }\end{array}$} & \multicolumn{4}{|c|}{ F Test with True Value 0 } \\
\cline { 3 - 8 } & $\begin{array}{c}\text { Lower } \\
\text { Bound }\end{array}$ & $\begin{array}{c}\text { Upper } \\
\text { Bound }\end{array}$ & Value & df1 & $\begin{array}{c}\text { df } \\
2\end{array}$ & Sig \\
\hline $\begin{array}{c}\text { Single } \\
\text { Measures }\end{array}$ & $.973^{\mathrm{a}}$ & .832 & .926 & 56.660 & 15 & 45 & .000 \\
\hline $\begin{array}{c}\text { Average } \\
\text { Measures }\end{array}$ & $.914^{\mathrm{c}}$ & .948 & .918 & 56.660 & 15 & 45 & .000 \\
\hline
\end{tabular}

Table 2. Reliability calculations using ICC

A two-way mixed-effects model where people effects are random and measures effects are fixed

a. The estimator is the same, whether the interaction effect is present or not b. Type $\mathrm{C}$ intraclass correlation coefficients using a consistency definition. The between-measure

c. This estimate is computed assuming the interaction effect is absent because it is not estimable otherwise.

\section{RESULTS AND DISCUSSIONS}

Lecturers who master practical courses in the Fashion Education Study Program obstacles while carrying out the online learning process. These constraints include: 1) the measurement of competence/student learning outcomes is not maximal, especially in product assessment; 2) have not found the suitable learning methods and assessment methods; 3 ) lack of student motivation to learn independently, and 4) lack of learning facilities owned by students.

All lecturers who master practice courses already use practice assessment instruments, but $54.5 \%$ of assessment instruments used have not used rubrics. $63.63 \%$ of instruments compiled are incompatible with Graduate Learning Achievement (CPL) and Practical Course Learning Achievement (CPMK), and only $36.36 \%$ of instruments can support the evaluation process in practice courses.

Rubrics in instruments have a very important role because rubrics can be used as a reference in assessing products made by students. Multipurpose assessment guidelines that can assess students' products and appearance are contained in an assessment rubric [19]. Rubrics should be able to support learning, which (1) is written in a language that is easy to understand; (2) defined and described in detail; (3) can be used to look at students' weaknesses; and (4) may be used to evaluate student assignments [20]. Instruments must also be adjusted to the achievements or learning goals set to measure students' abilities.

Assessment instruments used in the evaluation process $81.82 \%$ have never been socialized to students, so students do not know the assessment criteria used by lecturers in the course. $90.9 \%$ of instruments compiled by practice course lecturers were not tested for validity by the study group, $63.36 \%$ did not use pre-practice, practice, and post-practice components, and $81.8 \%$ found difficulty setting up practice assessment instruments. Criterion validity refers to the extent to which the instrument's score relates to the standard objective to be achieved [21].

Instruments before use must go through a validity test first because the validity and reliability of the instrument are categorized well if there is less error rate in the measurement [22]. The absolute requirement that must be met when developing an instrument is the validity of the instrument itself [23]. 
The development of practice assessment instruments is indispensable in the UNNES Fashion Education Study Program because the assessment instruments used by lecturers in assessing learning outcomes have not met the criteria of suitable instruments. A good instrument must meet the requirements of validity, reliability, sensitivity, objectivity, and feasibility.

\section{CONCLUSION}

The study revealed that 11 lecturers who taught practical courses $\mathrm{k}$ had used the practice assessment instrument. $54.5 \%$ of the assessment instruments used were not equipped with rubrics. $90.9 \%$ compiled by supporting lecturers were not tested for validity by the study group, $63.6 \%$ of practice assessment instruments did not use pre-practice, practice, and post-practice components, and $81.8 \%$ found difficulty in preparing instruments - practice assessment. Based on the study results, it is necessary to develop practice assessment instruments for the learning process during the Covid-19 pandemic.

\section{REFERENCES}

[1] J. H. McMillan, Classroom assessment : principles and practice that enhance student learning and motivation. 2018.

[2] D. M.-Y. UNY and undefined 2010, "Penilaian Pendidikan Karakter," academia.edu, Accessed: Oct. 09, 2021. [Online]. Available: https://www.academia.edu/download/32033941/Pe nilaian_karakter.pdf.

[3] A. C.-T. \& Learning and undefined 2008, "Bloom's taxonomy blooms digitally," teachnology.pbworks.com, 2008, Accessed: Dec. 05, 2021. [Online]. Available: http://teachnology.pbworks.com/f/Bloom\%5C's+T axonomy+Blooms+Digitally.pdf.

[4] A. Luxton-Reilly et al., "Bloom's taxonomy for CS assessment," academia.edu, 2008, Accessed: Dec. 05, 2021. [Online]. Available: https://www.academia.edu/download/40163596/C RPITV78Thompson.pdf.

[5] M. F.-E. perspectives on learning, undefined teaching, undefined and, and undefined 2010, "Bloom's taxonomy," d41.org, Accessed: Dec. 05, 2021. [Online]. Available: https://www.d41.org/cms/lib/IL01904672/Centricit y/Domain/422/BloomsTaxonomy.pdf.

[6] J. Arlinwibowo, H. Retnawati, B. Kartowagiran, and G. K. Kassymova, "Distance learning policy in Indonesia for facing pandemic COVID-19: School reaction and lesson plans," J. Theor. Appl. Inf. Technol., pp. 2828-2838, 2020.

[7] A. Abidah, ... H. H.-S. in P., and undefined 2020,
"The impact of covid-19 to indonesian education and its relation to the philosophy of 'merdeka belajar,", scie-journal.com, vol. 1, no. 1, pp. 3849, 2020, Accessed: Oct. 09, 2021. [Online]. Available: https://sciejournal.com/index.php/SiPoSE/article/view/9.

[8] H. Yulia, "Online learning to prevent the spread of pandemic corona virus in Indonesia," English Teach. J., vol. 11, no. 1, pp. 48-56, 2020.

[9] V. A. Scholtes, C. B. Terwee, and R. W. Poolman, "What makes a measurement instrument valid and reliable?," Injury, vol. 42, no. 3, pp. 236-240, 2011, doi: 10.1016/j.injury.2010.11.042.

[10] T. Widowati, W. P. Astuti, A. N. N. Ihsani, W. Prasetyaningtyas, L. Katarina, and A. Cristanti, "Analysis Of Practical Assessment Sheet Needs In Beauty Education Programs In State University," vol. 379, no. Veic, pp. 32-34, 2019, doi: 10.2991/assehr.k.191217.006.

[11] C. K. Azzahri, D. Widjanarko, and I. M. Sudana, "Pengembangan Instrumen Penilaian Praktik Rias Pengantin Jogja Paes Ageng pada Mata Kuliah Rias Pengantin Jawa," J. Vocat. Career Educ., vol. 2, no. 1, 2017, DOI: 10.15294/jvce.v2i1.10928.

[12] P. Instrumen and A. Mata, "PRAKTIK TATA BUSANA PADA PROGRAM STUDI PENDIDIKAN TATA BUSANA Jurusan Pendidikan Kesejahteraan Keluarga Universitas Pendidikan Ganesha," vol. 3, no. 1, pp. 326-336, 2014.

[13] E. Budiastuti, P. Karomah, A. Martanti, and D. Fatmawati, "Pengembangan Instrumen Self Assessment pada Praktik Menjahit Rok Berfuring," journal.uny.ac.id, [Online]. Available: https://journal.uny.ac.id/index.php/jptk/article/vie w/8848.

[14] C. Maharani, M. R. Susanto, and T. Mahanani, "PENGEMBANGAN INSTRUMEN PENILAIAN DIRI PADA SISWA TATA BUSANA DI YOGYAKARTA," journal.uny.ac.id, vol. 2, no. 1, 2017, [Online]. Available: https://journal.uny.ac.id/index.php/ptbb/article/vie w/36491.

[15] AERA, APA, and NCME, The Standards for Educational and Psychological Testing. 2014.

[16] L. R. Aiken, Psychological Testing and Assessment, 11th ed. 2003

[17] L. R. Aiken, "Three Coefficients for Analyzing the Reliability and Validity of Ratings:," http://dx.doi.org/10.1177/0013164485451012, vol. 45, no. 1, pp. 131-142, Sep. 2016, DOI: 10.1177/0013164485451012.

[18] D. V Cicchetti, “Guidelines, Criteria, and Rules of Thumb for Evaluating Normed and Standardized 
Assessment Instruments in Psychology," Psychol. Assess., no. 4, pp. 284-290, 1994.

[19] K. Wolf and E. Stevens, "The Role of Rubrics in Advancing and Assessing Student Learning.," J. Eff. Teach., vol. 7, no. 1, pp. 3-14, 2007.

[20] H. G. Andrade and B. A. Boulay, "Role of RubricReferenced Self-Assessment in Learning to Write," vol. 97, no. 1, pp. 21-30, 2010, DOI: $10.1080 / 00220670309596625$.

[21] C. B. Terwee et al., "Quality criteria were proposed for measurement properties of health status questionnaires," J. Clin. Epidemiol., vol. 60, no. 1, pp. 34-42, Jan. 2007, DOI: 10.1016/J.JCLINEPI.2006.03.012.

[22] A. M. Mayo, "Psychometric instrumentation: Reliability and validity of instruments used for clinical practice, evidence-based practice projects and research studies," Clin. Nurse Spec., vol. 29, no. 3, pp. 134-138, May 2015, DOI: 10.1097/NUR.0000000000000131.

[23] H. Retnawati, "Proving Content Validity Of SelfRegulated Learning Scale (The Comparison Of Aiken Index And Expanded Gregory Index)," Res. Eval. Educ. J., vol. 2, no. 2, pp. 123-146, 2016, [Online].

Available: http://routerjcs.nctu.edu.tw/router/word/11542212 017.pdf. 